Donald, C., Passey, B. I. \& Swaby, R. J. (1952). J. gen. Microbiol. 7, 211-220

\title{
A Comparison of Methods for Removing Trace Metals from Microbiological Media
}

\author{
By CATHERINE DONALD, BEVERLEY I. PASSEY AND \\ R. J. SWABY \\ Bacteriology Department, New Medical School, University of Sydney, \\ New South Wales, Australia
}

SUMMARY: Thirty-eight methods or modifications of methods for removing trace metals from nutrient media were tested, using Aspergillus niger as test organism to indicate deficiencies.

The most marked symptoms of $\mathrm{Zn}$ and $\mathrm{Fe}$ deficiencies were obtained after treatment by the $\mathrm{Al}_{2} \mathrm{O}_{3}$ or dithizone + oxine methods, of $\mathrm{Cu}$ and $\mathrm{Mn}$ deficiencies by the $\mathrm{Al}_{2} \mathrm{O}_{3}$ method, and of Mo deficiency by Nicholas's method which involves co-precipitation with sulphides of $\mathrm{Cu}$ and $\mathrm{Pb}$. Four strains of $\boldsymbol{A}$. niger differed in their trace element requirements. Shake cultures of $A$. niger gave less growth in complete medium than did surface cultures, while in deficient media this was reversed. Sucrose peptone and broth media were only partially purified by the $\mathrm{Al}_{2} \mathrm{O}_{3}$ treatment. Deficiencies of $\mathrm{Fe}, \mathrm{Zn}$ and $\mathrm{Cu}$ were obtained for Chlorella vulgaris, and of $\mathrm{Fe}$ and $\mathrm{Zn}$ for Torulopsis utilis, as detected by growth response. Apart from decrease of growth, trace metal deficiency symptoms in Penicillium roqueforti were not very obvious.

This paper summarizes work undertaken to compare the relative merits of most known methods for removing $\mathrm{Fe}, \mathrm{Zn}, \mathrm{Cu}, \mathrm{Mn}$ and $\mathrm{Mo}$ from culture media, including methods and modifications devised by the present authors.

Foster (1949) outlined many methods for freeing media from trace metals, without deciding which are the most efficient. Steinberg (1950) compared the relative merits of a number of techniques, only to find that his method, devised in 1919, which uses $\mathrm{CaCO}_{3}$ as an adsorbent, was superior to many advocated more recently.

The various methods available can be divided into two broad groups: (a) those which employ a solid such as charcoal or $\mathrm{CaCO}_{3}$ for adsorbing trace elements, the solid adsorbent being subsequently removed by filtration; (b) those which employ chelating agents such as diphenylthiocarbazone (dithizone) or 8-hydroxyquinoline (oxine), which combine with metals to form water-insoluble complexes that can be removed by extraction with organic solvents such as ether or carbon tetrachloride. In a few methods, both techniques are combined.

\section{MATERIALS AND METHODS}

Test organisms. Several strains of Aspergillus niger were tested: 540 and 543R, used for the commercial production of citric acid; M used by Mulder (1948) and 'Gerretsen' used by Gerretsen (1948) for determining the availability of trace elements in Dutch soils. In addition an alga, Chlorella vulgaris, 
and a yeast, Torulopsis utilis, were used. All stock cultures were maintained in tubes of liquid media treated with $\mathrm{Al}_{2} \mathrm{O}_{3}$ to remove trace metals, the treatment still leaving enough trace metals for maintenance in this way. Inocula were prepared by suspending a loopful of spores of $A$. niger, or cells of $C$. vulgaris and $T$. utilis, in $10 \mathrm{ml}$. of water twice distilled in glass, and seeding each flask with one drop from a sterile, acid-cleaned pipette.

Media. The basal medium for A. niger and T. utilis contained $50 \mathrm{~g}$. sucrose (commercial), 5 g. $\mathrm{KNO}_{3}$ (A.R.), $2 \cdot 5$ g. $\mathrm{K}_{2} \mathrm{HPO}_{4}$ (C.P.), and $0.5 \mathrm{~g} . \mathrm{MgSO}_{4} \cdot 7 \mathrm{H}_{2} \mathrm{O}$, made up to $1 \mathrm{l}$. with water from a tinned copper still. Nicholas's (1950) medium was used when testing his method for removing Mo. In order to decide whether the purification methods were effective, known amounts of trace metals were deliberately added to the medium before treatment. After purification a complete medium was prepared by adding recrystallized salts in the following amounts to $1 \mathrm{l} .: 200 \mu \mathrm{g}$. $\mathrm{Fe}$ (as $\mathrm{FeSO}_{4} .7 \mathrm{H}_{2} \mathrm{O}$ ); $180 \mu \mathrm{g}$. $\mathrm{Zn}$ (as $\mathrm{ZnSO}_{4} .7 \mathrm{H}_{2} \mathrm{O}$ ); $40 \mu \mathrm{g}$. $\mathrm{Cu}\left(\right.$ as $\mathrm{CuSO}_{4} .5 \mathrm{H}_{2} \mathrm{O}$ ); $20 \mu \mathrm{g}$. $\mathrm{Mn}$ (as $\mathrm{MnSO}_{4} \cdot 4 \mathrm{H}_{2} \mathrm{O}$ ); $10 \mu \mathrm{g}$. Mo (as $\left.\left(\mathrm{NH}_{4}\right)_{2} \mathrm{MoO}_{4}\right) ; 10 \mu \mathrm{g}$. B (as $\mathrm{H}_{3} \mathrm{BO}_{3}$ ). Trace metal deficient media were prepared by omitting the element in question.

C. vulgaris was grown in the following medium: 2 g. $\mathrm{NH}_{4} \mathrm{NO}_{3}$ (A.R.), 1 g. $\mathrm{K}_{2} \mathrm{HPO}_{4}$ (C.P.), $0 \cdot 25 \mathrm{~g} . \mathrm{MgSO}_{4} \cdot 7 \mathrm{H}_{2} \mathrm{O}$ (A.R.), made up with water from a tinned copper still to $1 \mathrm{l}$. Trace elements were deliberately added to the unpurified medium as above. After treatment trace metals, as the salts given above, were added where necessary in the following amounts, to 11 . of medium: $400 \mu \mathrm{g}$. Fe; $140 \mu \mathrm{g}$. Zn; $2 \mu \mathrm{g}$. Cu; $110 \mu \mathrm{g}$. Mn; $50 \mu \mathrm{g} . \mathrm{Mo} ; 50 \mu \mathrm{g} . \mathrm{B}$.

Attempts were also made to remove trace elements from more complex media, viz. sucrose $(5 \%)$ peptone water, and sucrose $(5 \%)$ ox heart broth, using the $\mathrm{Al}_{2} \mathrm{O}_{3}$ method.

All purified media were adjusted to $\mathrm{pH} 7$ before inoculation by adding either redistilled $\mathrm{NH}_{4} \mathrm{OH}$ or $6 \mathrm{~N}-\mathrm{HCl}$, except where otherwise stated. All glassware was cleaned by immersion in aqua regia overnight, followed by three rinses with water from a tinned copper still and three rinses with water twice distilled from glass.

Methods of cultivation. In static culture, $A$. niger was grown in $25 \mathrm{ml}$. of medium in $100 \mathrm{ml}$. Pyrex conical flasks, covered with inverted glass jars, or in Petri dishes $\left(10 \mathrm{~cm}\right.$. diameter), and incubated at $30^{\circ}$ for 7 days when maximum growth was achieved. The mycelium was then harvested, dried overnight at $40^{\circ}$, and weighed on a torsion balance. Shaken cultures were grown for 7 days at $30^{\circ}$ in $60 \mathrm{ml}$. medium contained in $1 \mathrm{l}$. reagent bottles covered with beakers, and shaken at the rate of 172 shakes/min. through a distance of $2 \mathrm{in}$.

T. utilis was grown in static culture as above and incubated at $30^{\circ}$ for 14 days; amount of growth was estimated by turbidity measurements.

C. vulgaris was grown in static and shaken cultures at $32^{\circ}$, illuminated by twelve $60 \mathrm{~W}$. incandescent electric lamps held at a height of $18 \mathrm{in}$. above the cultures. Incubation was continued for 14 days and the growth was estimated by turbidity measurements. 


\section{METHODS USED FOR REMOVING TRACE METALS}

Adsorption methods

(1) Steinberg's (1919) method using $\mathrm{CaCO}_{3}$ and autoclaving once.

(2) Steinberg's $\mathrm{CaCO}_{3}$ method modified by bubbling $\mathrm{H}_{2} \mathrm{~S}$ through the medium before autoclaving.

(3) Bortel's (1927) method using Norite charcoal.

(4) Mulder's (1948) method using Norite charcoal and $\mathrm{NH}_{4} \mathrm{HS}$.

(5) $\mathrm{Al}_{2} \mathrm{O}_{3}$ method. Five g. $\mathrm{Al}_{2} \mathrm{O}_{3}$ (British Drug Houses Ltd. chromatographic adsorption analysis material) were added to 1 l. of medium $(\mathrm{pH} 7 \cdot 5)$ in a $1.5 \mathrm{l}$. flask, which was shaken and autoclaved at $10 \mathrm{lb} . / \mathrm{sq}$.in. for $20 \mathrm{~min}$. On removal from the autoclave the hot contents were swirled to wet the inside of the flask. After standing overnight, the medium was sucked through an acid-treated, sintered-glass Buchner funnel connected by glass joints to a Pyrex filter flask. The filtrate was re-adjusted to $\mathrm{pH} 7$, and autoclaved.

The $\mathrm{Al}_{2} \mathrm{O}_{3}$ procedure was carried out at various $\mathrm{pH}$ values between 3.5 and $8 \cdot 5$, the most marked deficiency symptoms being obtained after using $\mathrm{Al}_{2} \mathrm{O}_{3}$ at $\mathrm{pH} 7 \cdot 5$. Acid-washed chromatographic $\mathrm{Al}_{2} \mathrm{O}_{3}$ gave no more marked deficiency symptoms, while $\mathrm{Al}_{2} \mathrm{O}_{3}$ (A.R.) was less effective.

(6) $\mathrm{Al}_{2} \mathrm{O}_{3}+\mathrm{H}_{2} \mathrm{~S}$ method. $\mathrm{H}_{2} \mathrm{~S}$ was bubbled through 1 l. of medium at $\mathrm{pH} r$ for 30 min., 5 g. chromatographic $\mathrm{Al}_{2} \mathrm{O}_{3}$ added, and the medium autoclaved at $10 \mathrm{lb}$. $\mathrm{sq}$.in. for $20 \mathrm{~min}$. After filtration the $\mathrm{pH}$ value of the filtrate was adjusted to 3 , the medium boiled and aerated to eliminate $\mathrm{H}_{2} \mathrm{~S}$, re-adjusted to $\mathrm{pH} 7$, then autoclaved.

(7) $\mathrm{Al}_{2} \mathrm{O}_{3}+\mathrm{CaCO}_{3}$ method. Two g. of chromatographic $\mathrm{Al}_{2} \mathrm{O}_{3}+5$ g. $\mathrm{CaCO}_{3}$ (A.R.) were added to 1 l. of medium at $\mathrm{pH} 8$, which was autoclaved as before, then filtered, the reaction of the precipitate adjusted to $\mathrm{pH} 7$, then autoclaved.

(8) Magnesium phosphate method. Magnesium phosphate was precipitated by adding $0 \cdot 25 \mathrm{~g}$. $\mathrm{MgSO}_{4} \cdot 7 \mathrm{H}_{2} \mathrm{O} / \mathrm{l}$. medium at $\mathrm{pH}$, autoclaving and filtering.

(9) Other adsorbents. Unsuccessful attempts were made to improve on the results obtained with $\mathrm{Al}_{2} \mathrm{O}_{3}$ by boiling various samples of media at $\mathrm{pH} 8$ with $\mathrm{MnO}_{2}, \mathrm{Fe}_{2} \mathrm{O}_{3}$, ionic exchange resins, humic acid, casein, albumin, bentonite, kaolin, or various soils.

(10) Nicholas's (1950) method for removal of Mo, which involves coprecipitation of sulphides of $\mathrm{Cu}, \mathrm{Pb}$ and $\mathrm{Mo}$ at $\mathrm{pH} 3$ and readjusting to $\mathrm{pH} 2$ prior to inoculation, as recommended by Nicholas. Nicholas's method often gave poor growth, probably because of residual traces of toxic sulphur compounds. Unsuccessful attempts were made to improve Nicholas's method by absorbing the Mo from boiling medium at $\mathrm{pH} 3$ on to $\mathrm{Al}_{2} \mathrm{O}_{3}$ (with or without $\mathrm{H}_{2} \mathrm{~S}$ ), washed sulphides of $\mathrm{Cu}$ and $\mathrm{Pb}$, flowers of sulphur moistened with ethanol, and colloidal sulphur formed by adding acidified sodium thiosulphate.

\section{Chelation methods}

(11) Diphenylthiocarbazone (dithizone). A purified solution of dithizone $(0.02 \%, \mathrm{w} / \mathrm{v})$ in redistilled $\mathrm{CCl}_{4}$ was prepared by the method of Piper (1944), and $100 \mathrm{ml}$. of this solution were added to 2 l. of medium adjusted to $\mathrm{pH} 9$ 
with redistilled $\mathrm{NH}_{4} \mathrm{OH}$. The mixture was shaken for 4 min. in a 2.51 . separating funnel on a reciprocal shaker at the rate of 172 shakes/min. through a distance of $2 \mathrm{in}$. The $\mathrm{CCl}_{4}$ layer was run off and the extraction repeated until $5 \mathrm{ml}$. of medium gave no pink colour when shaken with $\mathbf{1}$ drop of ammoniacal dithizone in $\mathrm{CCl}_{4}$. At least three extractions were necessary. Dithizone was removed from the medium at $\mathrm{pH}$ values of 9,7 and 4 by repeated washing with redistilled $\mathrm{CCl}_{4}$, three washings at each $\mathrm{pH}$ usually proving satisfactory. The medium was then boiled to eliminate $\mathrm{CCl}_{4}$, readjusted to $\mathrm{pH} 7$, and autoclaved.

(12) 8-Hydroxyquinoline (oxine). The following modification of Waring \& Werkman's (1942) method was used. Two l. of medium were shaken as above with $50 \mathrm{ml}$. of a solution of oxine $(0.5 \%, \mathrm{w} / \mathrm{v})$ in redistilled $\mathrm{CCl}_{4}$ at $\mathrm{pH} 9$. The $\mathrm{CCl}_{4}$ layer was run off, and the extraction repeated at least three times. The medium was then washed at $\mathrm{pH} 9$ and 7 with redistilled $\mathrm{CCl}_{4}$, and boiled to remove $\mathrm{CCl}_{4}$, then autoclaved.

(13) Dithizone + oxine. The batch of medium was repeatedly shaken as above, first at $\mathrm{pH} 9$ with oxine in $\mathrm{CCl}_{4}$, and then at $\mathrm{pH} 7$ with dithizone in $\mathrm{CCl}_{4}$. The chelating agents left in the medium were removed by repeated extractions at $\mathrm{pH} 9$ with redistilled $\mathrm{CCl}_{4}$ after the oxine extraction, and at pH 6 and 4 after the dithizone extraction. The medium was boiled to remove $\mathrm{CCl}_{4}$, adjusted to $\mathrm{pH} 7$ and autoclaved. This procedure was varied in several ways to determine the best conditions for the removal of trace metals, e.g. by adding the dithizone and oxine solutions together to the medium, and by making extractions at various $\mathrm{pH}$ values, viz. at 9 only, or at $9,8,7,6$ and 5 in succession. Deficiency symptoms were not more marked after successive extractions at $\mathrm{pH}$ values from 9 to 5 than at 9 only. However, dithizone was not removed completely from the aqueous layer after extraction at $\mathrm{pH} 9$ with $\mathrm{CCl}_{4}$, and yellow oxidation products were formed; dithizone was therefore used at $\mathrm{pH} \mathrm{7}$, at which $\mathrm{pH}$ value it is equally effective as a chelating agent. Deficiency symptoms were not more marked after extracting $10 \%$ solutions of sucrose and salts separately and making up to volume with water twice distilled in glass.

(14) Nicholas's (1950) method for removal of $\mathrm{Mn}$, which uses sodium diethyldithiocarbonate $(\mathrm{NaDDC})$ at $\mathrm{pH} 3 \cdot 4$, surplus chelating agent being removed by $\mathrm{Cu}$, and excess $\mathrm{Cu}$ by $\mathrm{H}_{2} \mathrm{~S}$.

(15) Nicholas's (1950) method for removal of Mo by co-precipitation with $\mathrm{Fe}$ in the presence of 8-hydroxyquinoline.

\section{RESULTS}

\section{Results with Aspergillus niger as test'organism}

The extent of removal of each trace metal was estimated by the diminution of growth below that obtained in a complete medium. However, in addition to this decrease in weight of mycelium, there were characteristic changes in the macroscopic and microscopic appearance of static cultures of the organism brought about by each specific deficiency (see Pl. 1). In Fe deficient cultures, 
mycelial growth was sparse with a few small black spore heads. With $\mathrm{Zn}$ deficiency, the mat was very thin, mainly submerged, and dotted with large black spore heads. $\mathrm{Cu}$ deficiency did not cause such a marked decrease in mycelium, but the spores lost their black pigment and with extreme deficiency spores were absent. In Mn deficiency, sporulation was almost absent and there was a marked decrease in weight of hyphae. Discrete papery colonies were formed instead of a continuous mat, giving a 'cauliflower' appearance, or in extreme deficiencies looking like 'puffed wheat'. In Mo deficient cultures, the mycelium was sparse, submerged, and almost devoid of spores.

Table 1. Comparison of methods for removing trace metals from sucrose $(5 \%)$ minerals medium using, as test organisms, two strains of Aspergillus niger, grown in static culture

\begin{tabular}{|c|c|c|c|c|c|c|c|c|}
\hline \multirow{3}{*}{$\begin{array}{l}\text { Method for removing } \\
\text { trace metals }\end{array}$} & \multirow{3}{*}{$\begin{array}{l}\text { Strain } \\
\text { of } \\
\text { A. niger } \\
\text { used }\end{array}$} & \multirow{3}{*}{$\begin{array}{c}\text { No. } \\
\text { of } \\
\text { tests }\end{array}$} & \multirow{3}{*}{$\begin{array}{l}\text { Dry weight of } \\
\text { mycelium in } \\
\text { complete medium } \\
\text { (g. } / 25 \mathrm{ml} .)\end{array}$} & \multicolumn{5}{|c|}{$\begin{array}{l}\text { Weight of mycelium in deficient } \\
\text { media, expressed as percentage } \\
\text { of that in complete media }\end{array}$} \\
\hline & & & & \multicolumn{5}{|c|}{ Metal deficiency } \\
\hline & & & & $\mathrm{Fe}$ & $\mathrm{Zn}$ & $\mathrm{Cu}$ & $\mathrm{Mn}$ & Mo \\
\hline (1) $\mathrm{CaCO}_{3}$ & $\mathbf{M}$ & 7 & $0 \cdot 39$ & 27 & $7 \cdot 5$ & $58 \cdot 5$ & 100 & 80 \\
\hline (2) $\mathrm{CaCO}_{3}+\mathrm{H}_{2} \mathrm{~S}$ & $\mathbf{M}$ & 2 & $0 \cdot 41$ & 29 & $9 \cdot 5$ & 74 & 100 & 100 \\
\hline (3) Norite & $543 R$ & 1 & $0 \cdot 20$ & 45 & $4 \cdot 5$ & 100 & 100 & 100 \\
\hline (4) Norite $+\mathrm{NH}_{4} \mathrm{HS}$ & $543 R$ & $\mathbf{1}$ & $0 \cdot 11$ & 21 & $3 \cdot 5$ & 72 & $86 \cdot 5$ & 100 \\
\hline (5) $\mathrm{Al}_{2} \mathrm{O}_{3}$ & $\mathbf{M}$ & 17 & $0 \cdot 43$ & 5 & 2 & 33 & 36 & 42 \\
\hline (6) $\mathrm{Al}_{2} \mathrm{O}_{3}+\mathrm{H}_{2} \mathrm{~S}$ & M & 1 & $0 \cdot 38$ & 30 & $10 \cdot 5$ & 100 & 100 & - \\
\hline (7) $\mathrm{Al}_{2} \mathrm{O}_{3}+\mathrm{CaCO}_{3}$ & $\mathbf{M}$ & 1 & $0 \cdot 37$ & 27 & $7 \cdot 5$ & 57 & 100 & 100 \\
\hline $\begin{array}{l}\text { (8) Magnesium phos- } \\
\text { phate } \\
\text { (10) Nicholas (removal }\end{array}$ & $\mathbf{M}$ & 1 & 0.40 & 10.5 & $10 \cdot 5$ & 65 & 100 & 74 \\
\hline Mo) & $\mathbf{M}$ & 5 & $0 \cdot 36$ & - & - & 一 & - & 11 \\
\hline (11) Dithizone & M & 1 & $0 \cdot 39$ & 33 & $1 \cdot 5$ & $45 \cdot 5$ & $73 \cdot 5$ & $84 \cdot 5$ \\
\hline (11) Dithizone & $543 \mathrm{R}$ & 2 & $0 \cdot 30$ & $65 \cdot 5$ & 4 & $54 \cdot 5$ & 80 & $21 \cdot 5$ \\
\hline (12) Oxine & $543 \mathrm{R}$ & 2 & $0 \cdot 29$ & $11 \cdot 5$ & $2 \cdot 5$ & 55 & $70 \cdot 5$ & 58 \\
\hline (13) Dithizone + oxine & $\mathbf{M}$ & 7 & 0.51 & 5 & 2 & 49 & $\mathbf{5 5}$ & 一 \\
\hline (13) Dithizone + oxine & $543 \mathrm{R}$ & 5 & 0.29 & 3 & 1 & $51 \cdot 5$ & $50 \cdot 5$ & 65 \\
\hline 4) Nichol & & & & & & & & \\
\hline $\begin{array}{l}\text { Mn) } \\
\text { Jichol }\end{array}$ & $\mathbf{M}$ & $\mathbf{I}$ & 0.52 & $25 \cdot 5$ & 4 & 100 & 63 & 28 \\
\hline $\begin{array}{l}\text { Nicholas ( } \\
\text { Mo) }\end{array}$ & $\mathbf{M}$ & 1 & 0.53 & - & - & - & - & 66.5 \\
\hline
\end{tabular}

Metal deficiencies revealed in static cultures. Table 1 shows the weights of mycelia of $A$. niger (strains $\mathrm{M}$ and 543R) grown in complete medium, and the weights in deficient media expressed as a percentage of that in complete medium. The most marked $\mathrm{Fe}$ deficiency symptoms were obtained with strain $\mathrm{M}$ after $\mathrm{Al}_{2} \mathrm{O}_{3}$ (method no. 5) and with strains $\mathrm{M}$ and $543 \mathrm{R}$ after dithizone + oxine treatments (no. 13), which gave mycelial yields of less than $5 \%$ of the maximum. Methods involving magnesium phosphate (no. 8), using strain $M$, or oxine (no. 12), using strain 543R R, were the next most effective, with yields in Fe-deficient media of 10.5 and $11.5 \%$ respectively; other treatments gave yields of $20-30 \%$ of the maximum, with the exception of the Norite treatment (no. 3) which had a yield of $45 \%$, and dithizone (no. 11), which gave a $33 \%$ yield with $M$ strain and $65 \%$ with $543 \mathbf{R}$. 
Zn was most effectively removed by $\mathrm{Al}_{2} \mathrm{O}_{3}$ (no. 5), dithizone (no. 11), and dithizone +oxine (no. 13), with yields of strain $M$ grown in deficient media of $2,1.5$ and $2 \%$ of the maximum respectively. With strain $543 \mathrm{R}$ most pronounced $\mathrm{Zn}$ deficiencies were achieved with dithizone +oxine (no. 13), dithizone (no. 11) and Norite charcoal $+\mathrm{NH}_{4} \mathrm{HS}$ (no. 4). By all treatments, the mass of growth was decreased to one-tenth or less of that in complete media. $\mathrm{Zn}$ is evidently comparatively easy to remove, even when present originally in fairly large amounts.

The most marked $\mathrm{Cu}$ deficiency with strain $\mathrm{M}$ was obtained after $\mathrm{Al}_{2} \mathrm{O}_{3}$ treatment (no. 5); good removal of $\mathrm{Cu}$ was also obtained by dithizone (no. 11) and by dithizone+oxine (no. 13). Of the methods used to induce $\mathrm{Cu}$ deficiencies in strain 543R methods 11, 12 and 13 were most successful. Even where no reduction in weight of mycelium occurred, there was a decrease in pigmentation.

Using strain $\mathrm{M}, \mathrm{Mn}$ was best removed by the $\mathrm{Al}_{2} \mathrm{O}_{3}$ treatment (no. 5), and with strains $\mathrm{M}$ and $543 \mathrm{R}$ dithizone + oxine (no. 13) was fairly effective. Even where there was no decrease in mass of growth, all methods of treatment caused some 'cauliflower' or 'puffed wheat' appearance, characteristic of Mn-deficient mycelium.

Mo deficiencies were difficult to obtain. Nicholas's adsorption (1950) method (no. 10 above) was most effective; medium so treated gave a yield with strain $M$ of only $11 \%$ of the maximum. Dithizone treatment (no. 11) gave $21.5 \%$ of the maximum yield of $543 \mathrm{R}$ in one case, but results with this method were erratic. Nicholas's (1950) method which uses NaDDC, and was designed for removing Mn (no. 14) was comparatively efficient for removal of Mo; yields with strain $\mathbf{M}$ of about $28 \%$ of the maximum were obtained by its use. $\mathrm{Al}_{2} \mathrm{O}_{3}$ (no. 5) and oxine (no. 12) gave 42 and $58 \%$ respectively, of maximum yield obtained from strains $M$ and $543 R$. Most other treatments gave no decrease in growth or visible change in macroscopic appearance.

From these results, it is concluded that method no. 5, using chromatographic $\mathrm{Al}_{2} \mathrm{O}_{3}$ gives better removal of $\mathrm{Cu}$ and $\mathrm{Mn}$ than any other method tested, and it is as effective as the dithizone + oxine method (no. 13) for removing $\mathrm{Zn}$ and $\mathrm{Fe}$, and not nearly so laborious. Nicholas's (1950) method involving co-precipitation with sulphides of $\mathrm{Cu}, \mathrm{Pb}$ and $\mathrm{Mo}$ (no. 10) was the most effective for removing Mo. In our experience, $\mathrm{CaCO}_{3}$ treatment (no. 1) is inferior to our $\mathrm{Al}_{2} \mathrm{O}_{3}$ method (no. 5), and only slightly better than adsorption by magnesium phosphate (no. 8). Methods involving Norite charcoal, $\mathrm{H}_{2} \mathrm{~S}$ or oxine, often gave poor growth in the treated medium, subsequently supplemented with essential trace metals, due to the introduction of toxic substances which were not completely removed.

Response of different strains of Aspergillus niger in various deficient media. Different strains of $\boldsymbol{A}$. niger were grown in $100 \mathrm{ml}$. conical flasks in batches of medium of the composition given above, but with only $2 \%$ sucrose, which had been rendered deficient in trace metals by various methods. The results are shown in Table $\mathbf{2}$, where the means of duplicates are quoted.

In a medium purified with dithizone (no. 11), strain 543 $\mathrm{R}$ produced more 
marked $\mathrm{Fe}, \mathrm{Zn}, \mathrm{Cu}$ and Mo deficiency symptoms than strain 540, while the reverse was true for $\mathrm{Mn}$ deficiency symptoms. In an oxine purified (no. 12) medium strain $\mathbf{5 4 0}$ showed the most marked deficiency symptoms of $\mathrm{Fe}, \mathrm{Zn}$, $\mathrm{Mn}$ and Mo, but $\mathrm{Cu}$ deficiency was greatest with strain 543 R. When the medium was purified with dithizone +oxine (no. 13) and four strains were tested, symptoms of $\mathrm{Fe}$ deficiency were most marked with strain 543R, of $\mathrm{Zn}$ deficiency with Gerretsen's strain, of $\mathrm{Cu}$ deficiency with strains $\mathrm{M}$ and 'Gerretsen', of Mn with strain 540, of Mo with strains 540 and 543R.

Table 2. Growth of strains of Aspergillus niger in static culture on sucrose (2\%) minerals medium treated by various methods to remove trace metals

\begin{tabular}{|c|c|c|c|c|c|c|c|}
\hline \multirow{2}{*}{$\begin{array}{l}\text { Method for removing } \\
\text { trace metals }\end{array}$} & \multirow{2}{*}{$\begin{array}{l}\text { Strain of } \\
\text { A. niger } \\
\text { used }\end{array}$} & \multirow{2}{*}{$\begin{array}{l}\text { Dry weight of } \\
\text { mycelium in } \\
\text { complete medium } \\
\text { (g. } / 25 \mathrm{ml} \text {.) }\end{array}$} & \multicolumn{5}{|c|}{$\begin{array}{c}\text { Weight of mycelium in deficient } \\
\text { media, expressed as percentage } \\
\text { of that in complete media } \\
\text { Metal deficiency }\end{array}$} \\
\hline & & & $\mathrm{Fe}$ & $\mathrm{Zn}$ & $\mathrm{Cu}$ & Mn & Mo \\
\hline Dithizone (no. 11) & $\begin{array}{l}540 \\
543 \mathrm{R}\end{array}$ & $\begin{array}{l}0 \cdot 10 \\
0 \cdot 14\end{array}$ & $\begin{array}{l}80 \\
74\end{array}$ & $\begin{array}{l}53 \\
22\end{array}$ & $\begin{array}{r}100 \\
63\end{array}$ & $\begin{array}{l}72 \cdot 5 \\
100\end{array}$ & $\begin{array}{l}100 \\
21 \cdot 5\end{array}$ \\
\hline Oxine (no. 12) & $\begin{array}{l}540 \\
543 \mathrm{R}\end{array}$ & $\begin{array}{l}0.09 \\
0 \cdot 12\end{array}$ & $\begin{array}{r}8 \\
17\end{array}$ & $\begin{array}{l}17 \\
56 \cdot 5\end{array}$ & $\begin{array}{l}90 \\
76 \cdot 5\end{array}$ & $\begin{array}{l}50 \cdot 5 \\
100\end{array}$ & $\begin{array}{r}75 \\
100\end{array}$ \\
\hline Dithizone + oxine & $\begin{array}{l}540 \\
543 \mathrm{R}\end{array}$ & $\begin{array}{l}0 \cdot 09 \\
0 \cdot 14\end{array}$ & $\begin{array}{l}8 \\
0\end{array}$ & $\begin{array}{r}17 \\
9\end{array}$ & $\begin{array}{l}90 \\
73\end{array}$ & $\begin{array}{l}50 \cdot 5 \\
87\end{array}$ & $\begin{array}{l}75 \\
75\end{array}$ \\
\hline No. 13 & $\begin{array}{c}\text { Gerretsen } \\
\text { M }\end{array}$ & $\begin{array}{l}0 \cdot 19 \\
0 \cdot 17\end{array}$ & $\begin{array}{l}25 \\
20 \cdot 5\end{array}$ & $\begin{array}{l}6 \\
8\end{array}$ & $\begin{array}{l}61 \\
60\end{array}$ & $\begin{array}{l}60 \\
55\end{array}$ & $\begin{array}{l}100 \\
100\end{array}$ \\
\hline
\end{tabular}

It is therefore concluded that Fe deficiency is best detected with strain $543 \mathrm{R}$ or 540 ; the $543 \mathrm{R}$, 'Gerretsen' and $\mathrm{M}$ strains are probably equally sensitive to $\mathrm{Zn}$ deficiency, and 'Gerretsen' and $\mathrm{M}$ to $\mathrm{Cu}$ deficiency. Strain 540 is most sensitive to lack of $\mathrm{Mn}$, and strain $543 \mathrm{R}$ the most sensitive to Mo deficiency, though response to Mo would be best tested in a medium purified by Nicholas's method (no. 10).

Metal deficiencies in complex media. Sucrose ( $5 \%$ ) broth and peptone were treated by the $\mathrm{Al}_{2} \mathrm{O}_{3}$ method (no. 5). The mycelial weights of $A$. niger, strain $\mathbf{M}$, obtained on these media after the addition of optimum amounts of trace elements were 0.50 and $0.51 \mathrm{~g}$. respectively, while the yields from the deficient media were 41 and $12 \%$ of the maximum respectively. Thus only partial removal of trace elements was achieved, but it was sufficient to show the usefulness of the method when applied to complex media.

Metal deficiencies revealed in shaken cultures. The results from three experiments showed that in complete medium, the weight of mycelium from shaken cultures was less than $62 \%$ of that from surface growth, whereas in deficient media, the yields from shaken cultures were greater than from the corresponding static ones. In a typical shaken culture experiment in which $A$. niger, strain $\mathrm{M}$, was grown in $60 \mathrm{ml}$. of medium treated by the $\mathrm{Al}_{2} \mathrm{O}_{3}$ method (no. 5), $0.67 \mathrm{~g}$. mycelium was obtained in the presence of optimum concentrations of trace elements. In batches of this medium deficient in $\mathrm{Fe}, \mathrm{Zn}, \mathrm{Cu}, \mathrm{Mn}$ or $\mathrm{Mo}$ the yields, as percentage of maximum, were: $29 \cdot 0,9 \cdot 8,94 \cdot 0,100$ and 108 
respectively. Pl. 2 illustrates the macroscopic appearance of the growth obtained. Static cultures gave $\mathbf{1} \cdot \mathbf{0 7} \mathrm{g}$. of mycelium from complete medium and yields, as percentage of maximum, of $9 \cdot 1,1 \cdot 3,59 \cdot 0,46 \cdot 0$ and $79 \cdot 0$, in media deficient in $\mathrm{Fe}, \mathrm{Zn}, \mathrm{Cu}, \mathrm{Mn}$ and Mo respectively.

\section{Results with other organisms}

Chlorella vulgaris. Media were purified by $\mathrm{CaCO}_{3}$, with (no. 2) and without (no. I) $\mathrm{H}_{2} \mathrm{~S}$, by dithizone + oxine (no. 13), by dithizone (no. 11), and by oxine (no. 12). In static and in shaken cultures growth of the alga was poorest in the Fe-deficient medium, almost white cells being produced. The growth of cells in the $\mathrm{Zn}$ - and Cu-deficient media was only slightly greater, and the cells were green. Media treated to remove Mn or Mo did not give smaller yields or alter the colour of the cells as compared with the results obtained in complete medium.

Torulopsis utilis. Only $\mathrm{Fe}$ and $\mathrm{Zn}$ deficiencies, obtained by using media purified with dithizone +oxine (no. 13), or with $\mathrm{CaCO}_{3}$ (no. 1), gave marked effects.

Penicillium roqueforti. This mould, grown for 17 days at $22^{\circ}$ in medium purified by the $\mathrm{Al}_{2} \mathrm{O}_{3}$ method (no. 5), gave decreased sporulation and yields in the absence of each trace element. The final $\mathrm{pH}$ values were in the range $7 \cdot 0-8 \cdot 0$, thus differing from $A$. niger, where $\mathrm{pH}$ values of $2 \cdot 5$ were not uncommon.

\section{DISCUSSION}

Many workers repeatedly recrystallize the ingredients of their media, and it is sometimes doubtful whether further purification by adsorbents or chelating agents achieves anything useful, but may even introduce contaminant trace metals or toxic substances. In the present work, methods of removing certain trace metals were tested, not with media made with recrystallized compounds, but with ingredients deliberately grossly contaminated with trace metals. In parenthesis, it may be noted that the A.R. products used frequently contained higher concentrations of $\mathrm{Zn}$ and $\mathrm{Cu}$ than did the corresponding C.P. or commercial grades.

It is not always clear in certain papers in the literature whether the 'complete' media used have been prepared by adding trace elements to purified or to unpurified media, thus making it difficult to decide wh ether th poorer growth sometimes recorded for purified medium was due to removal of micronutrients or to the introduction of toxic substances. In the present work, this uncertainty was eliminated by replacing optimum concentrations of micronutrients in media which had been treated to remove trace metals, and using the reconstituted medium as complete medium. Poor growth, or absence of growth due to toxic substances introduced into the medium, was sometimes found after treatment with $\mathrm{H}_{2} \mathrm{~S}$ or oxine. This is particularly important where chelating agents are used, since they are extremely difficult to remove completely from the medium, and their toxicity is influenced by the trace metal composition of the medium (Rubbo, Albert \& Gibson, 1950; 
Anderson \& Swaby, 1951). In many media there is enough magnesium and phosphate to precipitate magnesium phosphate on autoclaving at neutral $\mathrm{pH}$, and since this precipitate is able to remove traces of certain metals, the usefulness of an additional adsorbent may be in doubt. To obviate this criticism, the present authors used low concentrations of magnesium which, however, were sufficient for maximum growth. Sometimes all the salts used were reported to have been treated with a chelating agent except the $\mathrm{MgSO}_{4} \cdot \mathbf{7} \mathrm{H}_{2} \mathrm{O}$ which, in our experience, is often grossly contaminated with heavy metals.

None of the methods tested for removing trace elements is entirely satisfactory for studying bacterial nutrition. Several species of bacteria capable of growth in the medium used for $A$. niger gave such small amounts of cells in complete medium that it is doubtful whether they would have exhausted the residual traces of micronutrients in purified media sufficiently to show decreased growth. Methods which use chelating agents are more laborious, may introduce toxic substances, and give no greater deficiencies than the $\mathrm{Al}_{2} \mathrm{O}_{3}$ method, which proved the most efficient of the adsorption methods for removing $\mathrm{Fe}, \mathrm{Zn}, \mathrm{Cu}$ and $\mathrm{Mn}$. It is important to stress the need for swirling the flask to suspend the $\mathrm{Al}_{2} \mathrm{O}_{3}$ both before and after autoclaving. Filtration through acid-washed filter-paper is not as satisfactory as filtration through a fine sintered-glass filter connected by ground glass joints to a vacuum flask. There is no advantage in using a column of adsorbent. Slightly greater deficiency symptoms are achieved by repeating the $\mathrm{Al}_{2} \mathrm{O}_{3}$ treatment several times on one batch of medium. It is not known how adsorbents remove cations of trace metals, but the process may be analogous to cation exchange with complex silicates and synthetic resins, since for all these there is an optimum $\mathrm{pH}$ value for maximum effect and desorption can be induced by high concentrations of salts. Adsorbents like $\mathrm{Al}_{2} \mathrm{O}_{3}$, metal sulphides, and $\mathrm{CaCO}_{3}$, which probably possess lower electrical charges per unit surface than do silicates and resins, are preferable to these last two adsorbents, since they do not appreciably affect the major element constitution of the medium.

The authors wish to acknowledge financiai assistance from the Commonwealth Research Grant. They are also indebted to Dr E. G. Mulder and Dr F. C. Gerretsen for providing their strains of $A$. niger, and to $\mathrm{Mr} \mathrm{S}$. Woodward-Smith of the Department of Medical Artistry, University of Sydney, for the photographs.

\section{REFERENCES}

Anderson, B. I. \& Swaby, R. J. (1951). Factors influencing the fungistatic action of 8-hydroxyquinoline (oxine) and its metal complexes. Aust. J. sci. Res. B, 4,275 .

Bortels, H. (1927). Über die Bedeutung von Eisen, Zink und Kupfer für Mikroorganismen. Biochem. $Z .182,301$.

Foster, J. W. (1949). Chemical Activities of Fungi. New York: Academic Press Inc.

Gerretsen, F. C. (1948). On the use of Aspergillus niger for the determination of plant nutrients in the soil. Anal. Chim. Acta, 2, 782.

Mulder, E. G. (1948). The microbiological estimation of copper, magnesium and molybdenum in soil and plant material. Anal. Chim. Acta, 2, 793. 
Nichol.As, D. J. D. (1950). Use of Aspergillus niger for determining magnesium, copper, zinc and molybdenum in soils. J. Sci. Food Agric. 1, 339.

Piper, C. S. (1944). Soil and Plant Analysis. Adelaide: University of Adelaide Press.

Rubbo, S. D., Alrbert, A. \& Gibson, M. I. (1950). The influence of chemical constitution on antibacterial activity. V. The antibacterial action of 8-hydroxyquinoline (oxine). Brit. J. exp. Path. 31, 425.

Sternberg, R. A. (1919). A study of some factors in the chemical stimulation of the growth of Aspergillus niger. Amer. J. Bot. 6, 330.

Steinberg, R. A. (1950). Trace element impurities in nutrient solutions for fungi. Arch. Biochem. 28, 111.

Waring, W. S. \& Werkman, C. H. (1942). Growth of bacteria in an iron-free medium. Arch. Biochem. 1, 303.

\section{EXPLANATION OF PLATES}

\section{Plate 1}

Appearance of $A$. niger strain $\mathrm{M}$ grown on defined medium purified with $\mathrm{Al}_{2} \mathrm{O}_{3}$ (method no. 5), showing characteristic changes brought about by each specific deficiency.

\section{Plate 2}

Appearance of shaken cultures of $A$. niger strain M grown in defined medium purified with $\mathrm{Al}_{2} \mathrm{O}_{3}$ (method no. 5), showing characteristic changes brought about by each specific deficiency. 
Journal of General Microbiology, Vol. 7, Nos. 3 and 4

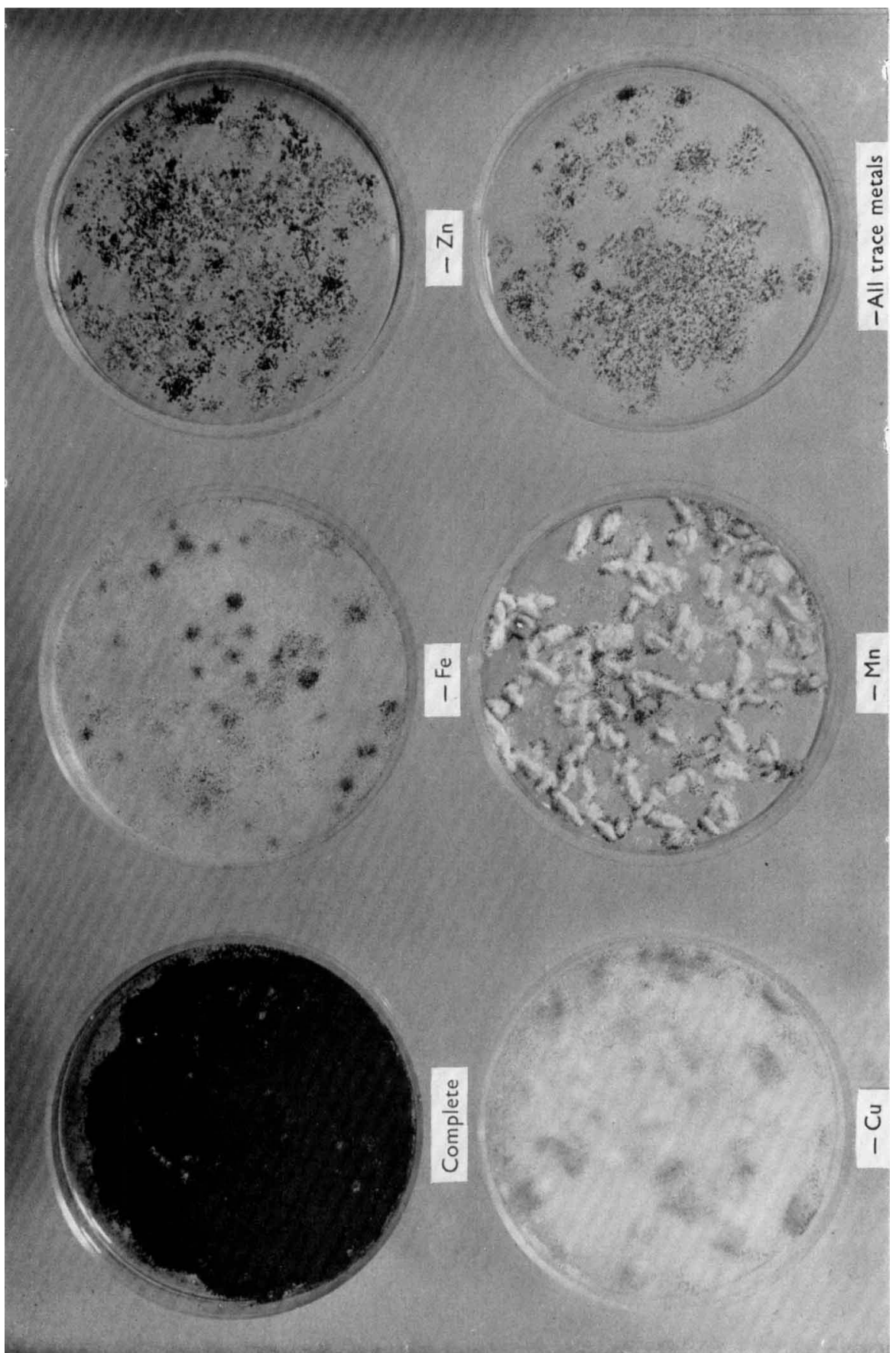

Catherine Donald, Beveriey I. Passey ind R. J. Swaby -Removal of trach mealls From media. Plate 1 
Journal of General Microbiology, Vol. 7, Nos. 3 and 4

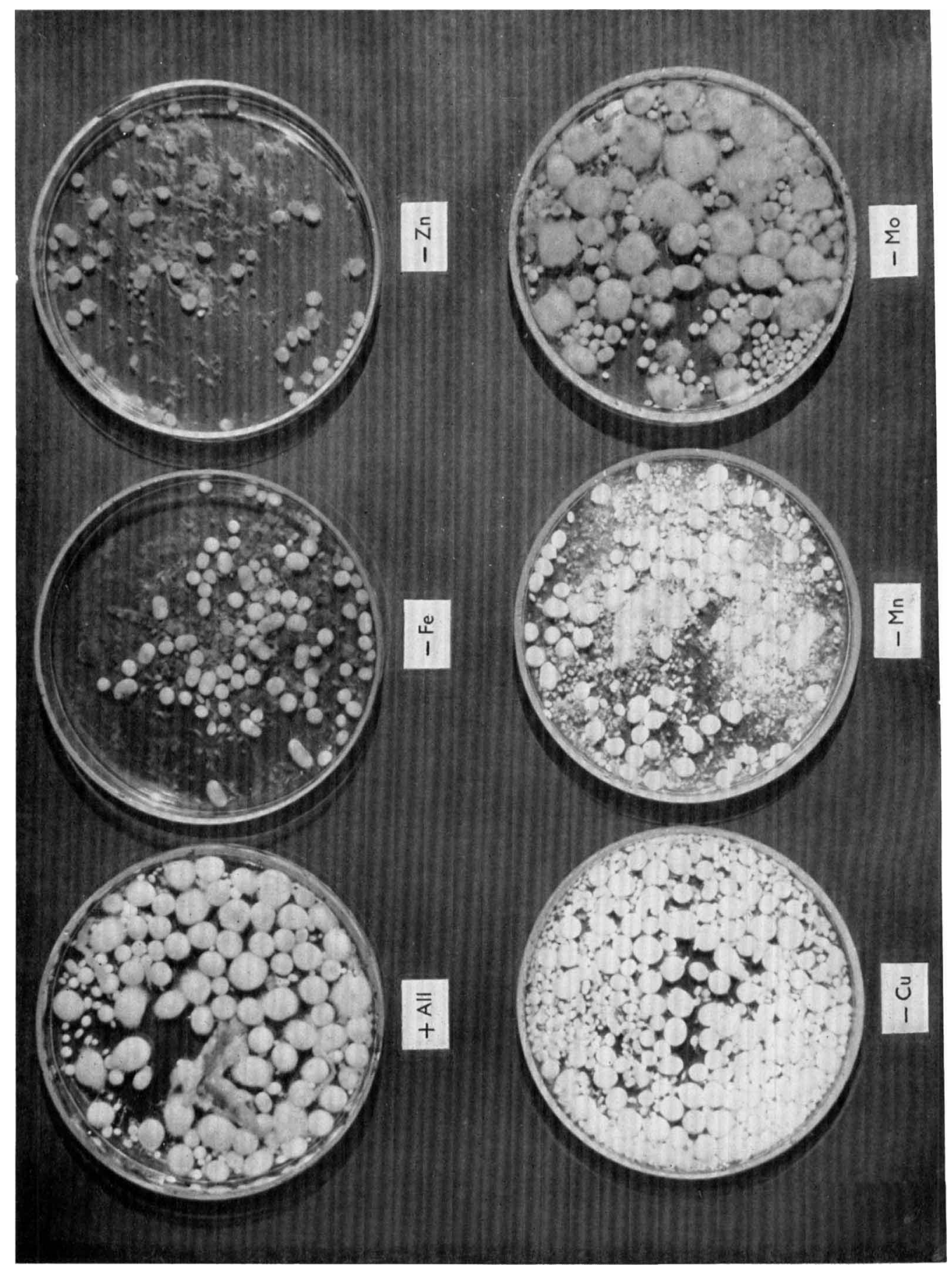

Catherine Donald, Beveriey I. Passey and R. J. Swaby-Removal of trace metals From Media. Plate 2 